\title{
Ethnic identity and cultural elements: Students' views
}

\author{
Panagiotis Efstratios Giavrimis (Corresponding author) \\ Lecturer, Department of Sociology, University of the Aegean \\ Greece
}

Email: pgiavrimis@gmail.com

Emmanouil Tsagkatos

Ministry of Education and Religious Affairs, Greece

\section{Vicky Sargioti}

Ministry of Education and Religious Affairs, Greece

Doi:10.5296/ jsr.v6i1.7116 URL: http://dx.doi.org/10.5296/ jsr.v6i1.7116

\begin{abstract}
Ethnic identity, as a symbolic construction, is structured through a complex and multi-faceted process, which is in constant evolution. From childhood to adolescence ethnic identity is shaped by experiences and representations, whereas the importance that children give in ethnic identity is growing year by year. The purpose of this paper is to explore the aspects of Greek students' ethnic identity in compulsory education and their association with the feeling of origin and the preservation of cultural elements. The sample is composed of 327 students in Chios island. In conclusion, an ambivalence emerges in the formation of ethnic identity, which highlights the acculturational osmosis of the islands in the North Aegean Sea, in an era of ' fluidity ' and social interdependencies that spread from local to global environment.
\end{abstract}

Keywords: Ethnic identity, compulsory education 


\section{Introduction}

The concept of identity refers both to individuals (personal identity), and collectivities (social identity) (Jenkins 1996. Oyserman et al.,2004). According to Goffman (2005), personal identity relates to the uniqueness of the subject and is shaped through the evolution of time and from one's personal path within the society. According to Prelorentzou and Dalla (2003: 31 ) identity operates on three processes. Assimilation: Reception and integration of new elements in the structure of identity. Compliance: The person modifies the existing structure to include new elements. Evaluation: The person assesses the elements that will be assimilated in the structure of identity. The evaluation process contributes to the enhancement of the person's self-esteem. The modern conceptualization of identity is a complex and multi-faceted process, which is in constant evolution (Gewirtz \& Cribb, 2011) in contrast to classical approach, where identity had a static form and in greater extent represented features that man had conquered (Kowert \& Legro, 1996, p. 453). Pavlopoulos and Besevegis (2008) refer to three levels of confronting identity: (a) Intrapersonal level: removing, acceptance, reassessment, (b) Interpersonal level: isolation, negativism, going ahead, compliance and (c) Intergroup level: participation in multiple groups, group support, group action-interaction. The theory of social identity, which was expressed by Tajfel \& Turner (1979), shows as a central parameter for the shaping of social identity the contradistinction of the self-image that in-groups offer each person with the corresponding out-groups. The group acquires great dynamic as psychological processes develop, within the group, which affect the personality and the character of the person who belongs to the team. However, this dynamic does not grow to such a great extent on dyadic relationships (Georgogiannis, 1996: 56). Under the influence of postmodernism and the debates about multiculturalism, since the late 1980s, many social scientists increasingly argue that in order to explore identity, various characteristics should be examined relating to race, class, ethnicity, gender, sexuality, ethnicity and other social categories (Alcoff \& Mendieta, 2003). The dynamic form of identity is a theoretical approach that is identified mostly with the postmodern era, encloses elements of deconstruction of tradition, interpretative analysis of social phenomena and alternative introduction of digital technology (Hogg \& Abrams, 1988).

\subsection{Ethnic identity and Greece}

Ethnic identity is a symbolic construction that appeared to replace the void which was created by the breakdown of the traditional form of social organization, in which religion had the central role and to offer members of modern societies a new basis for achieving and creating the "imaginary community" of the nation based on the existence of common cultural elements (Anderson, 1991). Ethnic identity is based on the representations that each ethnic group has for itself and other nations and is referred to common origin in order to legitimize the group's recommendation in an independent political unity (Fragoudaki \& Dragona, 1997, pp. 14-15). Ethnic identity is characterized as a social construction with socio-historical dimensions (Veikos 1999. Hall, 1997) and refers to a common geographical-historical place, to common ancestral traditions and historical memories, to a common culture, common obligations and rights (Smith, 1991, p. 14), as well as to a collective imprinting of the subjectivity of "belonging" to a nation, having common language, religion, customs and 
traditions (Gkotovos, 2002). Ethnic identity belongs to the category of social identities as the person is part of a group, that is the group of people who have common language, religion, customs, tradition and history. The value of homogeneity leads to the degradation of other social identities except ethnic identity (Fragkoudaki, 1997: 152). Social consensus and intergroup uniformity are important factors to maintain unity in the group. Any deviation from the truth of the majority is dangerous for breaking up the balance, an important element that intergroup functions must have (Papastamou, 1989: 18). The need for uniformity and cultural purity creates feelings of xenophobia, isolation and dismissal/disapproval of diversity (Fragkoudaki, 1997: 154). Ethnic identity often identifies with ethnic identity. But they are different, since ethnic identity is defined as the "sense of belonging to an ethnic group as well as the perceptions, thoughts, feelings and behaviours that derive from the individual's participation in this group" (Besevegis et al., 2010). But the ethnic identity, as shown in passports and other official documents, does not always manage to shield the members of a group from the distinction (Gkotovos, 2001: 52).Ethnic identity is included in every aspect of our daily lives: in our diet, clothing, language, habits and education, forming the frame of its function (Billig, 1995).

As far as childhood is concerned, ethnic identity is shaped by experiences and representations. During early childhood, children have not yet got any awareness of the concept of identities, but knowing about the existence of the ethnic group will be investigated empirically. Surveys, that took place in England, showed that during childhood-adolesence the importance that children give in ethnic identity is growing year by year (Barret, 2000). Ethnic identity is constructed mostly through speech, but it can also be enhanced with cultural elements (ritualistic behaviours etc.), while the use of language idioms is used as a symbol of ethnic identity (Hall, 1997, p. 184).

Greek ethnic identity has been associated with common origin, cultural heritage, and religion (Triandafyllidou, 1998, p. 490) continuity, homogeneity, superiority, patriotism and bravery (Avdela 1997). According to Gropas \& Triantafyllidou (2009, p. 13-14) ethnic identity of Greek people, as formed in the 20th century, was developed in a nexus of relations between; (a) the construction and perception of ethnic and European identity, (b) the modernity and tradition, which resulted in the ideologically confused sense of "Greek-Christianism" and (c) the country's position at the crossroad, both geographically and culturally, between East and West. The differentiation of Greek ethnic identity is perceived as 'something different' and is imprinted in the social formation as minority. Furthermore, Greek identity is characterized as "restricted" or "inflexible" (Stratoudaki, 2005), having a defensive form, which has permeated all school textbooks (Vamvakidou, Golia, Kassidou \& Zigouri , 2010). According to the survey of the General Secretariat for Youth, the majority of Greek youngsters $(64.3 \%)$ feel ' very ' or ' fairly ' proud of their identity. The vast majority of young people $(75.1 \%)$, refers to the ancient Greek culture and folk tradition as the most important factors of building ethnic consciousness, while they reject the "European" identity. It is also emerged that young people reject the European identity to a large extent (G.S.F.Y., 2005). According to Stratoudaki's survey (2005) the majority of students feel proud of their ethnicity, having as the most important values their family, friends, democracy and religion. One in four students, 
according to the survey's results, may be classified as "ethnocentric." At the same time, social institutions such as family, school, friends and the media contribute to the shaping of their ethnic identity, having many times opposite guidelines, which emerge through stereotypes and prejudices.Greek bibliography surveys highlight these opposite attitudes (Kavounidi, Konti, Lianos \& Fakiolas, 2008. Tsigkanou, 2010. VPRC, 2007).

The purpose of this paper is to explore aspects of ethnic identity of Greek students in compulsory education in Chios island and associate them with the feeling of origin and the preservation of cultural items.

\section{Methodology}

\subsection{Sample}

The reference population in this research, is the total population of students attending in the Sixth Grade of Primary School and in the 1st and 2nd years of Junior High School in Chios island. Chios island is situated on the islands of the North Aegean Sea (Greece), forming the outer southeastern borders of the European Union. Since Chios is an island and because of the geographical discontinuity that results from this, there are socio-economic and educational inequalities. Moreover Chios and generally the islands of the North Aegean Sea are portals of entry and residence of immigrants. In total, 1536 students attend in all 3 classes. We applied to 327 students coming from all social classes. 60 of them $(36.1 \%)$ were students in the 6th Grade, 52 ( $31,3 \%$ ) were students in the $1^{\text {st }}$ year of Junior High School and 54 $(32.5 \%)$ were students in the $2^{\text {nd }}$ year of Junior High School. $169(51.7 \%)$ of the students are boys and $158(48.3 \%)$ are girls.

\subsection{Research tool}

Phinney's questionnaire (1992) was used as the basis of the present investigation, which was formed appropriately for the requirements of our research. Phinney's questionnaire (1992) (Multigroup Ethnic Identity Measure - MEIM) is composed of 12 questions. The MEIM questionnaire was created in order to measure the process of development of ethnic identity in adolescents (12 years and over) and young adults. It has been used in dozens of studies and has consistently shown good reliability, usually with alpha over 0.80 (a > 0.80) in a wide range of ethnic groups and ages. The questions of the MEIM questionnaire were translated and reformulated in order to be understood by the students of our research. The questionnaire, before been distributed to schools for completion by the students, was tested experimentally in 30 students of the corresponding ages of the target research, in order to detect any shortcomings and misinterpretations. The questions were divided into three categories; (a) Demographic Characteristics (Gender, Age, Ethnicity, Class, School achievement, educational level of parents), (b) Questions of the MEIM questionnaire and (c) Questions of sociological interest in relation to ethnic identity. Roberts et al. (1999), using factor analysis in a large sample of adolescents, found that measurement (measure) is more preferable to be separated into two levels (factors); (a) the Exploration of ethnic identity (a developmental, cognitive process) and (b) the Identity Commitment (an emotional, behavioural process). The two factors of the MEIM questionnaire (Exploration/Commitment) were used in this research. 


\section{Mll Macrothink}

The reliability for the MEIM factors was factor for the Exploration Cronbach $\mathrm{a}=0.608$ and for the factor Commitment Cronbach a $=0.741$.

\section{Findings}

Combining the two factors of ethnic identity, Exploration and Commitment, and making use of the "clusters" analysis, we classified people, according to Marcia (1966), in a subset of "clusters" depending on the statement of the individuals' identity. "Cluster analysis" uses the similarities among individuals or cases in relation to given variables (in our case these variables were the factors of ethnic identity) for their classification. So, with the use of the above method we ended up into four groups.

Table 1. Clusters Centers

\begin{tabular}{|l|l|l|l|l|}
\hline \multicolumn{2}{|l|}{ Cluster } \\
\hline $\begin{array}{l}\text { Dimensions of ethnic } \\
\text { identity }\end{array}$ & $\begin{array}{l}\text { Achieved } \\
\text { Identity }\end{array}$ & $\begin{array}{l}\text { Diffused } \\
\text { Identity }\end{array}$ & Moratorium & $\begin{array}{l}\text { Foreclosed } \\
\text { Identity }\end{array}$ \\
\hline Identity Search & 4.80 & 2.40 & 4.00 & 2.20 \\
\hline Identity Commitment & 4.86 & 2.29 & 3.00 & 4.29 \\
\hline
\end{tabular}

Observing the clusters centers (tab. 1)which are produced by the "cluster analysis" we find out that the four "clusters" that are created have the following characteristics; (a) The first "cluster" (Achieved Identity) is characterized by high exploration and commitment to ethnic identity, (b) in contrast, the second "cluster" (Diffused Identity) is characterized by low exploration and commitment to ethnic identity, (c) the third "cluster" (Moratorium) is characterized by high exploration and low commitment to ethnic identity and (d) the fourth "cluster" (Foreclosed Identity) is characterized by low exploration and high commitment to ethnic identity. The classification of students on groups were as follows; Achieved Identity;135 individuals(41.3\%),Diffused Identity ;35 individuals (10.7\%), Moratorium;131 individuals $(40.1 \%)$ and Foreclosed Identity;26 individuals $(8.0 \%)$. The majority of the sample is in the process of Moratorium and Achieved Identity. The four groups are different with statistical significance $\left[\chi^{2}(3)=13.711, p=0.003\right]$, highlighting the diversity of forms of ethnic identity of individuals.

Secondly, the correlations of the forms of identity (Achieved Identity, Diffused Identity, Moratorium, Foreclosed Identity ) of Greek students were examined with their answers to the question" I feel good that I come from this country and I have this cultural background ". The analysis of the results showed a statistical significant correlation $\left[\chi^{2}(12)=79.162, p=0.000\right]$. We can mention that the various identities are associated with the conceptualization of the individuals' feelings in relation to their origin and their cultural background (tab 2). People with "Diffused Identity" waver in a rate of $34.3 \%$ which is not expressed by any other group to this extent, they are the least satisfied with their origin in relation to the other forms of 
identity. Furthermore, almost all the people with "Achieved Identity" emphasize their satisfaction at their origin and cultural background. The remaining groups range between the two extremes of satisfaction that the two previous groups of identities delimit, while those with 'Moratorium' identity tend to be more happy.

Table 2. Identity, country of origin and cultural background

\begin{tabular}{|c|c|c|c|c|c|c|}
\hline \multirow{2}{*}{$\begin{array}{l}\text { Ethnic } \\
\text { Identity }\end{array}$} & \multicolumn{5}{|c|}{$\begin{array}{l}\text { I feel good that I come from this country and I have this } \\
\text { cultural background }\end{array}$} & \multirow{2}{*}{ Total } \\
\hline & SD & Disagree & NA/ND & Agree & SA & \\
\hline $\begin{array}{l}\text { Achieved } \\
\text { Identity }\end{array}$ & $\begin{array}{l}0 \\
(0.0 \%)\end{array}$ & $0(0.0 \%)$ & $5(3.7 \%)$ & $26(19.3 \%)$ & $\begin{array}{l}104 \\
(77.0 \%)\end{array}$ & $\begin{array}{l}135 \\
(100 \%)\end{array}$ \\
\hline $\begin{array}{l}\text { Diffused } \\
\text { Identity }\end{array}$ & $\begin{array}{l}1 \\
(2.9 \%)\end{array}$ & $2(5.7 \%)$ & $12(34.3 \%)$ & $8(22.9 \%)$ & $\begin{array}{l}12 \\
(34.3 \%)\end{array}$ & $\begin{array}{l}35 \\
(100 \%)\end{array}$ \\
\hline Moratorium & $\begin{array}{l}0 \\
(0.0 \%)\end{array}$ & $0(0.0 \%)$ & $19(14.5 \%)$ & $46(35.1 \%)$ & $\begin{array}{l}66 \\
(50.4 \%)\end{array}$ & $\begin{array}{l}131 \\
(100 \%)\end{array}$ \\
\hline $\begin{array}{l}\text { Foreclosed } \\
\text { Identity }\end{array}$ & $\begin{array}{l}1 \\
(3.8 \%)\end{array}$ & $\begin{array}{l}3 \\
(11.5 \%)\end{array}$ & $4(15.4 \%)$ & $9(34.6 \%)$ & $\begin{array}{l}9 \\
(34.6 \%)\end{array}$ & $\begin{array}{l}26 \\
(100 \%)\end{array}$ \\
\hline Total & $\begin{array}{l}2 \\
(0.6 \%)\end{array}$ & $5(1.5 \%)$ & $40(12.2 \%)$ & $89(27.2 \%)$ & $\begin{array}{l}191 \\
(58.4 \%)\end{array}$ & $\begin{array}{l}327 \\
(100 \%)\end{array}$ \\
\hline
\end{tabular}

Note: SD; Strongly Disagree, NA/ND; Neither Agree Nor Disagree, SA; Strongly Agree

Thirdly, the correlations of the dimensions of identity (Achieved Identity, Diffused Identity, Moratorium, Foreclosed Identity) of Greek students were examined with their answers to the question "I like to use elements from my country of origin". The analysis of the results showed a statistical significant correlation $\left[\chi^{2}(12)=44.414, p=0.000\right]$. We can mention that the various identities are associated with the use of elements from the cultural background of their country (tab 3). Characteristically, it is observed that people with "Diffused Identity" waver in a rate of $22.9 \%$ which is not expressed by any other group to this extent. Additionally, almost everybody with "Achieved Identity" emphasize their total satisfaction at their origin and cultural background. Also, individuals with "Foreclosed Identity" tend not to use the elements of their country in the same way as the other groups, while their agreement in this view has the lowest rate. The rest groups, range between the two extremes of satisfaction that the two previous groups of identities delimit. 


\begin{tabular}{|c|c|c|c|c|c|c|}
\hline \multirow{2}{*}{$\begin{array}{l}\text { Ethnic } \\
\text { Identity }\end{array}$} & \multicolumn{5}{|c|}{ I like to use elements from my country of origin } & \multirow{2}{*}{ Total } \\
\hline & SD & Disagree & NA/ND & Agree & SA & \\
\hline $\begin{array}{l}\text { Achieved } \\
\text { Identity }\end{array}$ & $\begin{array}{l}0 \\
(0.0 \%)\end{array}$ & $0(0.0 \%)$ & $2(1.5 \%)$ & $\begin{array}{l}43 \\
(31.9 \%)\end{array}$ & $\begin{array}{l}90 \\
(66.7 \%)\end{array}$ & $\begin{array}{l}135 \\
(100,0 \%)\end{array}$ \\
\hline $\begin{array}{l}\text { Diffused } \\
\text { Identity }\end{array}$ & $\begin{array}{l}1 \\
(2.9 \%)\end{array}$ & $3(8.6 \%)$ & $8(22.9 \%)$ & $\begin{array}{l}12 \\
(34.3 \%)\end{array}$ & $\begin{array}{l}11 \\
(31.4 \%)\end{array}$ & $\begin{array}{l}35 \\
(100,0 \%)\end{array}$ \\
\hline Moratorium & $\begin{array}{l}1 \\
(0.8 \%)\end{array}$ & $2(1.5 \%)$ & $13(9.9 \%)$ & $\begin{array}{l}41 \\
(31.3 \%)\end{array}$ & $\begin{array}{l}74 \\
(56.5 \%)\end{array}$ & $\begin{array}{l}131 \\
(100.0 \%)\end{array}$ \\
\hline $\begin{array}{l}\text { Foreclosed } \\
\text { Identity }\end{array}$ & $\begin{array}{l}1 \\
(3.8 \%)\end{array}$ & $0(0.0 \%)$ & $4(15.4 \%)$ & $\begin{array}{l}9 \\
(34.6 \%)\end{array}$ & $\begin{array}{l}12 \\
(46.2 \%)\end{array}$ & $\begin{array}{l}26 \\
(100.0 \%)\end{array}$ \\
\hline Total & $\begin{array}{l}3 \\
(0.9 \%)\end{array}$ & $5(1.5 \%)$ & $27(8.3 \%)$ & $\begin{array}{l}105 \\
(32.1 \%)\end{array}$ & $\begin{array}{l}187 \\
(57.2 \%)\end{array}$ & $\begin{array}{l}327 \\
(100.0 \%)\end{array}$ \\
\hline
\end{tabular}

Table 3. Identity and elements of the country of origin

\section{Discussion}

Ethnic identity is part of social identity and has to do with the integration of individuals into groups with common cultural, linguistic and religious characteristics, which provide the individual a sense of safety, security, confidence and a sense of "belonging". Taking into account the dynamic way in which individuals negotiate and build their ethnic identity, we can say that students in Chios island, who are associated with both the educational system (textbooks, teachers, students and parents) and the wider social environment in which they live, produce their various forms of identity differentiating them according to their individual, social and cultural resources. According to Tsaousis(1997) the adjustment of ethnic identity is associated with the social environment and the cultural elements that each time make up the basis of differentiation and contradistinction. The strategic of positioning themselves in a form of ethnic identity is constituted in relation to others and is made by setting limits and exclusions. Main factor in the reproduction of ethnic identity is the State Educational System (Avdela, 1997, p. 33). Greek students are part of an educational system that reinforces their own cultural elements by giving them a dominant entity. Due to this process, the majority of Greek students have Achieved Identity. Students with Diffused Identity and Moratorium are in a process of transition and they try to combine different cultural narratives, values and commitments, defining their attitudes and their moods in relation to all these. Therefore, the correlation with their feelings about their country of origin has variations. This process is also part of the individuals' ability to stand reflectively towards their identity. Students with 
Achieved Identity and Foreclosed Identity are at a later stage to create their identity, have crystallized their attitudes to various cultural elements of their environment and their views are characterized by greater stability. Besides, as a member of a group, the individual acquires emotional and ideological ties with the group in which he belongs and participates (Tajfel, 1972, p.292), sets himself inside it and endorses the stereotypical rules of this group (Turner, 1981, p. 108).

In conclusion, the ambivalence (Achieved Identity, Diffused Identity, Moratorium, Foreclosed Identity) that emerges in the formation of ethnic identity is declarative of the accultural osmosis that exists, along with the effort to harmonize the conflicting cultures and ,to a large extent, the ensuring of the individual's mental balance (Phinney, Horenczyk, Liebkind \& Vedder, 2001). Of course, in a period (in a state of 'liquidity') of social interdependencies ranging from local to global environment, where daily life is reconstituted under the negotiations that are performed between the social subjects, the reflection process even for those with Achieved Identity or Foreclosed Identity ,is maybe something inevitable, demonstrating the dynamic part of building ethnic identity. Greek society, and by extension the Greek educational system is necessary to develop intercultural understanding, to recognize and respect cultural diversity in everyday practice. The promotion of the principles of acceptance and diversity, the recognition of the cultural capital of vulnerable groups in the curriculum and the training of teachers in intercultural education can define the framework for conceptualization and formation of a functional ethnic identity from individuals.

\section{References}

Alcoff, L. M., \& Mendieta, E. (Eds.) (2003). Identities: Race, class, gender and ethnicity. Malden, MA: Blackwell.

Anderson, B. (1991). Imagined Communities. London: Routledge.

Barrett, M. (2000). The development of ethnic identity in childhood and adolescence. Retrieved 2/1/2014 from http: //epubs.surrey.ac.uk/1642/1/00_Inaugural_lecture.pdf

Billig, M.(1995). Banal ethnicism. London: Sage.

Gewirtz, Sh. \& Cribb, A. (2011). Understanding education. Athens: Metechmio.

Gropas, R. \& Triandafyllidou, A. (2009). The state of the art: various paths to modernity. Greek case. Athens: ELIAMEP

Hall, J. M. (1997). Ethnic Identity in Greek Antiquity. Cambridge: Cambridge Univ. Press

Hogg, M. \& Abrams, D. (1988). Social Identications: A Social Psychology of Intergroup Relations and Group Processes. London: Routledge.

Jenkins, R. (1996), Social Identity. London: Routledge

Kowert, P. \& Jerey, L. (1996). Norms, Identity, and Their Limits. In P. Katzenstein (ed.), The Culture of Ethnic Security, (pp. 451-497). New York: Columbia University Press.

Marcia, J. E. (1966). Development and validation of ego identity status. Journal of 
Personality and Social Psychology, 3(5), 551-558.

Oyserman, D., Bybee, D., Terry, K., \& Hart-Johnson, T. (2004). Possible selves as roadmaps. Journal of Research in Personality, 38 (2), 130-149.

Phinney, J. (1992), The Multigroup Ethnic Identity Measure. Journal of Adolescent Research, 7, 156-176.

Phinney, J.S., Horenczyk, G., Liebkind, K. \& Vedder, P. (2001). Ethnic identity, immigration, and well-being: An interactional perspective. Journal of Social Issues, 57, 493-510.

Tajfel, H., \& Turner, J. C. (1979). An integrative theory of intergroup conflict. In W. G. Austin 8c S. Worchel (Eds.), The social psychology of intergroup relations (pp. 33-47). Monterey, CA: Brooks/Cole.

Turner, J.C. (1981). The experimental social psychology of intergroup behavior. In J.C. Turner \& H. Giles (eds.), Inter-group behavior (pp. 66-101). Oxford: Blackwell.

Vamvakidou I., Golia P., Kassidou S. \& Zigouri E., (2010), The perceptions of "Homeland": Greek universities students define the term. Procedia Social and Behavioral Sciences, 2, 4546-4550.

VPRC (2007). Attitudes and perceptions of Greek society towards immigrants. Athens.

Avdela, E. (1997). The formation of ethnic identity in Greek school: 'we' and 'others'. In A. Fragoudaki \& Th. Dragona (eds.) What is our homeland: Ethnocentrism in Education (pp. 27-45). Athens: Alexandria.

Veikou, Th. (1999). Ethnicism and ethnic identity. Athens: Greek Letters.

General Secretariat for Youth (2005). The Youth in Greece today. Athens: University of Athens, Department of Media and ALCO. Retrieved January 2, 2014 from:

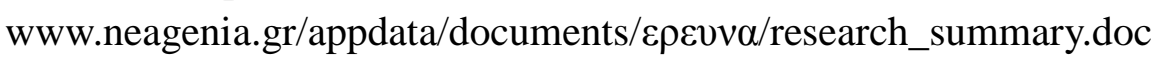

Georgogiannis, P. (1996), Theories of Social Psychology, Volume 2, Athens: Gutenberg.

Gkotovos, A. (2001), Globalization, Otherness and Identity: The Renegotiation of meaning of Education, Ioannina.

Gkotovos, A. (2002). Education and diversity. Athens: Metechmio.

Goffman, E. (2005). The presentation of self in everyday life. Translation: Gkofra, M., Athens: Alexandria.

Kavounidi, T., Konti, A., Lianos, T., \& Fakiolas, R. (2008). Immigration in Greece: Experiences-Policies-Prospects. Athens: IMEPO

Besevegis. E., Pavlopoulos, B.\& Georganti K. (2010). Ethnic identity and psychosocial adjustment: an empirical research on the second generation immigrant teenagers. Athens: Department Of Psychology, Faculty Of FPPs, UOA \& IMEPO.

Papastamou, S. (1989), Social Influence, Contemporary researches in social psychology, eds.: 


\section{Macrothink}

Papastamou, S, Transl: Katiforis, K. \& Stamatakis, N., Athens: Odysseas.

Papastamou, S. (1989), Social Influence. Athens: Odysseas.

Prelorentzou, E. \& Dalla, M. (2003), Characteristics of the psychological adaptation of immigrant students from Albania to Greece. In: Education Topics, No. 13/2003, quarterly inspection of education policy and research.

Stratoudaki, Ch. (2005). Nation and Democracy: Aspects of Ethnic Identity of adolescents. Social Researches, 116 (A), 23-50.

Triandafyllidou A. (1998). The "others" among us-Greek ethnic identity and attitudes towards immigrants. In The Sam. S. Karagiorga (eds.). Social inequalities and social exclusion (p. 488-498). Athens: Exandas.

Tsaousis, D., G. (1997). Social demography. Athens: Gutenberg.

Tsigkanou, I. (Eds.) (2010). European Social Survey. Athens: EKKE. Retrieved December 20, 2012 from: www.ekke.gr/html/gr/NewsEvents/ESS4_results.pdf

Fragkoudaki, A. \& Dragona, Th. (eds.) (1997). What is our homeland: Ethnocentrism in education. Athens: Alexandria.

Fragoudaki, A. (1997) The political consequences of the ahistorical presentation of the Greek nation In: Fragoudaki, A. \& Dragona, Th. (eds.), (1997), What is our homeland: Ethnocentrism in Education, second edition. Athens: Alexandria. 